\title{
T TALLACHIAN SETTLERS IN THE BALTIC SEA REGION. A HUMANIST TALE OF MIGRATION AND COLONIZATION, AND ITS IMPLICATIONS FOR THE MENTAL MAPS OF EARLY MODERN EUROPE
}

\section{Stefan Donecker}

Alfried Krupp Wissenschaftskolleg Greifswald, E-Mail: stefan.donecker@eui.eu

\section{Acknowledgments}

The article is based on a paper presented at the Second International Conference of the Romanian Association for Baltic and Nordic Studies: Black Sea and Baltic Sea Regions: Confluences, influences and crosscurrents in the modern and contemporary ages, at Târgovişte, May 20-22, 2011. I would like to express my gratitude to the organisers for their kind invitation. Furthermore, I would like to thank the Stiftung Alfried Krupp Kolleg, Greifswald, which generously funded the underlying research on migration narratives in early modern thought, and the Österreichische Forschungsgemeinschaft (project MOEL-415), whose support enabled me to explore the life and writings of Friedrich Menius.

\begin{abstract}
:
During the 1550s, humanists at the University of Wittenberg in Germany first suggested that Wallachians from present-day Romania had migrated to the Baltic Sea, settled in Livonia and became the ancestors of Estonians and Latvians. This colonization allegedly took place at some time in the $5^{\text {th }}$ or $6^{\text {th }}$ century $A D$. Although such a theory seems bizarre from a modern point of view, it was considered a perfectly reasonable hypothesis by contemporary scholars. For approximately 150 years, up to the early $18^{\text {th }}$ century, the idea of a Wallachian colonization of Livonia retained its place in the historiography of the region, before it was refuted by the more sober-minded approach of enlightenment historians. The paper provides an overview of the scholarly theories on a kinship between Wallachians, Estonians and Latvians that were formulated between 1550 and 1700. Although these fanciful hypotheses are not supported by any discernible historical facts, they provide important insights on the position of Wallachia and Livonia in the symbolic geography and the mental maps of the early modern res publica litterarum.
\end{abstract}




\begin{abstract}
Rezumat:
In anii 1550, umaniştii de la Universitatea din Wittenberg, Germania, au sugerat pentru prima dată că valahii din România de azi au migrat spre Marea Baltică, sau stabilit în Livonia şi au devenit strămoşii estonienilor şi letonilor. Această colonizare se presupune că a avut loc la un moment dat, în secolul al V-lea sau al VI-lea d. Hr. Deşi o astfel de teorie pare bizară din punct de vedere modern, aceasta a fost considerată o ipoteză perfect rezonabilă de către cercetători contemporani. Pentru aproximativ 150 de ani, până la începutul secolului al XVIII-lea, ideea unei colonizări valahe a Livoniei a reținut locul său în istoriografia regiunii, înainte de a fi respinsă de abordarea mai echilibrată a istoricilor iluminişti. Lucrarea oferă o imagine de ansamblu a teoriilor ştiințifice privind o înrudire între valahi, estonieni şi letoni, care au fost formulate intre anii 1550 şi 1700. Deşi aceste ipoteze fanteziste nu sunt sprijinite de fapte istorice perceptibile, ele oferă perspective importante cu privire la pozițiile Valahiei şi Livoniei în geografia simbolică şi în hărțile mentale de la începutul res publica litterarum moderne.
\end{abstract}

Keywords: Livonia, Wallachia, migration, genealogy, mental maps, early modern historiography

\title{
Introduction
}

In May 2011, the Second International Conference of the Romanian Association for Baltic and Nordic Studies discussed historical encounters and mutual influences between the Black Sea and the Baltic Sea Region, from the Middle Ages up to the present. The nations and societies of Eastern Europe's two great inland seas indeed share, as the conference's proceedings proved, a fascinating and multi-faceted history, with manifold interactions of a political, diplomatic, economic as well as a cultural nature. To the numerous historical connections between the Baltic Sea and the Black Sea littoral, I would like to contribute a rather unusual addition: the settlers from Wallachia who colonized the lands of the eastern Baltic 1,500 years ago and became the ancestors of Estonians and Latvians.

Apparently, the connection between the Baltic and the Black Sea region is, in this particular case, a purely imaginary one: In historical reality, there have never been any Wallachian colonizers in the eastern Baltic area, and the forefathers of the Latvians and the Estonians certainly did not come from present-day Romania. Yet humanist scholars of the $16^{\text {th }}$ and $17^{\text {th }}$ centuries believed they did, and their opinion in this peculiar matter certainly deserves closer scrutiny.

In the history of historiography the distinction between fact and fiction tends to be blurred: Fictionality is, as the eminent German 
medievalist Hans-Werner Goetz ${ }^{1}$ has pointed out, an inadequate criterion for the evaluation of historiographic texts. If an occurrence that would be regarded as "fictional" by modern scholars corresponds to the firm conviction of a historical author, it is, as Goetz argues, the latter's truth, irrespectively of any present-day evaluations. To us, as modern researchers, the idea of a Wallachian colonization on the Baltic shores seems rather strange - but to early modern men of letters, it was a legitimate and plausible hypothesis. As I intend to show in the following pages, it provides interesting insights into the way $16^{\text {th }}$ and $17^{\text {th }}$ century scholars perceived the lands situated at the Black Sea and the Baltic Sea. As an expression of the mental maps of eastern Europe in the early modern Republic of Letters, the tale of these elusive Wallachian pioneers is far more than just a random humanist fable.

\section{Caspar Peucer, the Chronicon Carionis and the "Discovery" of the Wallachian Settlers}

In 1565, one of the most influential tomes of early modern historiography was published at Wittenberg, the center of Protestant humanism in Germany: Chronicon Carionis, the "Chronicle of Carion", in a revised version edited by Caspar Peucer (1525-1602), the rector of Wittenberg University. ${ }^{2}$ The impressive, four-volume history of the entire world bears the name of Johannes Carion (1499-1537), mathematician and astrologer at the court of Elector Joachim I. of Brandenburg. Carion was the author of a comparatively modest chronicle, published in $1532 .{ }^{3}$ After his untimely death - attributed by contemporaries to his excessive drinking habits -, his teacher, Philipp Melanchthon (1497-1560), the influential humanist and close collaborator of Luther, revised Carion's chronicle and published two greatly improved and expanded volumes in 1558 and 1560, covering the world's history from the Creation to the reign of Charlemagne. Melanchthon himself died in April 1560, and his son-in-law Caspar Peucer continued his work on the chronicle. The two final volumes were published in 1562 and 1565. The chronicle retained the name of its

\footnotetext{
1 Hans-Werner Goetz, "'Konstruktion der Vergangenheit'. Geschichtsbewusstsein und 'Fiktionalität' in der hochmittelalterlichen Chronistik, dargestellt am Beispiel der Annales Palidenses," in Von Fakten und Fiktionen. Mittelalterliche Geschichtsdarstellungen und ihre kritische Aufarbeitung, ed. J. Laudage (Köln: Böhlau, 2003), 232.

2 Philippus Melanthon and Casparus Peucerus, Chronicon Carionis expositum et auctum [...] ab exordio mundi usque ad Carolum V. Imperatorem (Wittenberg: Krafft, 1580).

${ }^{3}$ Cf. Frank Prietz, "Geschichte und Reformation. Die deutsche Chronica des Johannes Carion als Erziehungsbuch und Fürstenspiegel," in Universitas. Die mittelalterliche und frühneuzeitliche Universität im Schnittpunkt wissenschaftlicher Disziplinen. Georg Wieland zum 70. Geburtstag, ed. O. Auge, C. Dietl (Tübingen and Basel: Francke, 2007).
} 
original author, Chronicon Carionis, mainly out of respect for the deceased scholar, since the final version, after meticulous revisions, bears little resemblance to Carion's original text.

The Chronicon Carionis, in the revised version of Melanchthon and Peucer, was a great success, one of the main achievements of Wittenberg humanism. ${ }^{4}$ It was reprinted repeatedly and became the quasi-official history textbook of Lutheran Europe. Generations of German and Scandinavian scholars received their initiation to universal history from Melanchthon and Peucer, and the influence of the Chronicon Carionis on $16^{\text {th }}$ and $17^{\text {th }}$ century historiography can hardly be overestimated.

To Philipp Melanchthon, the history of the eastern Baltic area was a topic of particular interest. He was greatly alarmed by the Muscovite attack on Livonia in 1558 and followed the subsequent developments in the region closely. ${ }^{5}$ After Melanchthon's death, Peucer retained this emphasis on Livonian history, with the result that the eastern Baltic is wellrepresented in the Chronicon Carionis - the first major work of universal history that devoted considerable attention to the region and its history. According to Melanchthon's methodology, any historical inquiry had to take the origins of the local population into account: "Knowledgeable men have always sought the origins of nations," Melanchthon had stated programmatically. ${ }^{6}$ Consequently, the Chronicon Carionis, in particular Peucer's fourth and final volume, contains several interesting speculations on the origins and ancestry of the Estonians and Latvians. ${ }^{7}$

The most remarkable passage, in this respect, establishes a genealogical connection between the indigenous inhabitants of Livonia and the Wallachians of the lower Danube: "In addition to the Germanic and the Slavonic tongue 8 , one can observe three more languages ${ }^{9}$ [in Livonia] which are distinct from the former and also differ from each other. One of them, which is called 'Estonian', relates, in certain words, to the Latin language, though in a very corrupt form, so that it is truly not dissimilar

\footnotetext{
${ }^{4}$ Cf. Matthias Pohlig, Zwischen Gelehrsamkeit und konfessioneller Identitätsstiftung. Lutherische Kirchen- und Universalgeschichtsschreibung 1546 - 1617 (Tübingen: Mohr Siebeck, 2007), 175189, with an overview of older research.

5 Robert Stupperich,"Melanchthon und Hermann Wittekind über den livländischen Krieg," Zeitschrift für die Geschichte des Oberrheins 103 (1955): 275-281.

${ }_{6}^{6}$ Melanthon and Peucerus, 184. Cf. Hildegard Ziegler, Chronicon Carionis. Ein Beitrag zur Geschichtschreibung des 16. Jahrhunderts (Halle: Niemeyer, 1898), 51.

7 Stefan Donecker, Origines Livonorum. Frühneuzeitliche Hypothesen zu Herkunft und Ursprung der 'undeutschen' Livländer (PhD thesis, Florence: EUI, 2010), 161-166.

8 In the original Latin "Heneta lingua", the Wendish language.

${ }^{9}$ Estonian, Latvian and Couronian. The latter was usually regarded as a separate language by early modern observers.
} 
from Latin. For this reason, several people have remarked, based on the argument of name and language, that the Lithuanians are descendants of the Wallachians - who are Latin colonists - and that the Livonians in the vicinity of Reval, in turn, descend from the Lithuanians. The name of the people of Reval also alludes to the Wallii or Wallachi."10

Caspar Peucer implies that this extraordinary theory is not his own idea: Aliqui annotarunt, "certain people" have remarked that the Livonians descend from the Wallachians. Among Melanchthon's pupils there were several young Baltic German noblemen from Livonia who had been attracted by the reputation of the University of Wittenberg, and it seems likely that some of them provided Caspar Peucer with information about their native land, including the alleged Wallachian ancestry of the Estonian peasants. Paul Johansen ${ }^{11}$, one of the leading $20^{\text {th }}$ century experts in this field, has singled out a certain Hermann von Nehmen, a rather insignificant student from Dünamünde (Daugavgriva ${ }^{12}$ ), as one of Melanchthon's and Peucer's main informers on Livonian matters. Another possible source would be Hermann Wittekind, a former pupil of Melanchthon. His teacher's recommendation secured Wittekind a position at the cathedral school in Riga, and he regularly corresponded with Melanchthon and updated him on developments in Livonia. ${ }^{13}$

The main argument for the existence of a Wallachian colony in the Baltic area is the similarity between Estonian, Lithuanian and Latin. The reference to Estonian is, in this context, rather surprising. A certain resemblance between Latvian and Latin seems less far-fetched; both languages do, after all, belong to the Indo-European family. A similarity between Latin and Finno-Ugric Estonian is far more difficult to imagine.

Peucer, however, was unfamiliar with the languages of Livonia and had, probably, received misleading statements from his local informers. As a result, he tended to confuse Estonian and Latvian. ${ }^{14}$ Peucer probably wanted to refer to Latvian when he commented on similarities between Latin and one of the barbarian languages of Livonia, but got it wrong and wrote "Estonian" instead. Previously, in the introduction to the fourth

\footnotetext{
10 Melanthon and Peucerus, 477.

11 Paul Johansen, "Die Legende von der Aufsegelung Livlands durch Bremer Kaufleute," in Europa und Übersee. Festschrift fur Egmont Zechlin, eds. O. Brunner, D. Gerhard (Hamburg: Hans Bredow-Institut, 1961), 50-51.

12 In this paper, I use the historical German toponyms with the modern Estonian and Latvian names added in brackets.

13 Stupperich, 276-277.

14 On one occasion, Peucer claimed that the inhabitants of Reval called their city "Danopil", "the castle of the Danes" - a Latvian equivalent to Estonian "Tallinn", which would have been the appropriate designation in this context. Cf. Melanthon and Peucerus, 477.
} 
volume, he had avoided this mistake and clarified that the language derived from the Wallachian settlers was called "die lettische Sprach", "the Latvian tongue". ${ }^{15}$

Another factor, which certainly contributed to Peucer's uncertainty, was the alleged reference to the Wallachians contained in the name "Reval": Nomen Revaliensium ad Wallios seu Wallachos alludit, "the name of the people of Reval alludes to the Wallachians". Peucer was infamous for his creative etymologies and his enthusiasm for superficial similarities between random unrelated ethnonyms and toponyms. ${ }^{16}$ According to this method, Riga had been founded by the Rugii, mentioned by Tacitus as inhabitants of northern Germany, and Narva derives its name either from the Nervii in Gaul or the Neuri in distant Scythia. Livonia itself is named after the Lemovii, an obscure tribe documented only in a single occasion in Tacitus' Germania, or the Leuonoi who inhabited Scandinavia, according to Ptolemy. "I enjoy following and retaining etymologies," Peucer explained, "which demonstrate the nature, the customs and the character of a nation as well as its dwelling places." 17

This onomastic method, rather absurd from a modern point of view but perfectly acceptable to the standards of $16^{\text {th }}$ century scholarship, led Peucer to the conclusion that the second syllable of the name Re-val indicates that the city's founders had been Wallachians. Together with the alleged similarities between Latin and the local indigenous idiom, this evidence implied that Livonia had once been colonized by Romanianspeaking settlers from the lower Danube. The supposedly convincing reference to Wallachians in the name Reval seems to have prompted Peucer to shift the emphasis from southern Livonia (where a linguistic similarity between Latin and Latvian would have been somewhat plausible) to the north of the country, resulting in the unlikely connection between IndoEuropean Wallachians and Finno-Ugric Estonians.

Yet despite all its shortcomings, Peucer's theory of a Wallachian colony in the eastern Baltic area proved very influential: The authority of the Chronicon Carionis and its prominent authors was undisputed among $16^{\text {th }}$ and $17^{\text {th }}$ century scholars, and the tale of the intrepid Romanian settlers, implausible as it might seem from a modern point of view, enjoyed considerable credence for more than a century. ${ }^{18}$

\footnotetext{
15 Melanthon and Peucerus, 304.

16 Cf. Donecker 2010, 163-164. On etymological onomastics in early modern scholarship, ibid., 41-42.

17 Melanthon and Peucerus, 296. Cf. Ziegler, 54.

18 Cf. Donecker 2010, 228-239.
} 


\section{Lithuanian Examples: Prince Palemon and the Romans}

According to Caspar Peucer there was no direct connection between the Wallachians and the peasants of Livonia: A Walachis [...] Lituanos, ab his Livonios ad Revaliam ortos esse: the Livonians descend from the Lithuanians, and the Lithuanians, in turn, from the Wallachians. ${ }^{19}$ This is quite an important detail, because it indicates the origin of the entire theory: The idea that the eastern Baltic littoral is populated by descendants of the Wallachians is, essentially, based on Lithuanian traditions.

Early modern scholars claimed that the Grand Duchy of Lithuania had been founded by exiled noblemen from ancient Rome ${ }^{20}$, famously led by a certain Palemon. ${ }^{21}$ The tale was first recorded by the Polish chronicler Jan Długosz (1414-1480)22 and has been a feature of Lithuanian historiography since the early $16^{\text {th }}$ century, when it was first elaborated in the chronicles of the so-called Second Redaction. The alleged Roman origins of the Lithuanians became extremely popular in the latter half of the $16^{\text {th }}$ century, after the Union of Lublin (1569) reduced Lithuania to an inferior position in the Polish dominated Rzeczpospolita. A Roman heritage was an extremely prestigious genealogy that provided the Lithuanian elites with a viable argument for an improved standing in the Polish-Lithuanian Commonwealth.

In 1564, Vilnius humanist Augustinus Rotundus (1520-1582) introduced a new name for the Lithuanian founding hero: In his "Conversations of a Pole with a Lithuanian", Rotundus claims that the Roman prince who later became known as Palemon had, initially, been called Publius Libo. Two years later, Rotundus promoted his new version of the Lithuanian origins in a Latin tract, Epitome Principum Lituaniae. ${ }^{23}$ Through

\footnotetext{
${ }^{19}$ Melanthon and Peucerus, 477.

${ }^{20}$ For a recent overview of the Lithuanian-Roman genealogy in German resp. English, cf. Mathias Niendorf, Das Großfürstentum Litauen. Studien zur Nationsbildung in der Frühen Neuzeit (1569-1795) (Wiesbaden: Harrassowitz, 2006), 58-62; Artūras Tereškinas, Imperfect Communities. Identity, Discourse and Nation in the Seventeenth-Century Grand Duchy of Lithuania (Vilnius: Lietuvių literatūros ir tautosakos institutas, 2005), 254-263. Cf. also Elżbieta Kulicka, "Legenda o rzymskim pochodzeniu Litwinów i jej stosunek do mitu sarmackiego," Przeglad Historyczny 71 (1980): 1-21.

${ }^{21}$ According to the original version of the story, Prince Palemon had been a contemporary of Emperor Nero in the first century AD. Later reformulations of the story moved him to the fifth century AD and stated that he and his followers had fled the tyranny of Attila and the Huns. Cf. Donecker 2010, 230-231.

22 Ioannes Długossus, Historiæ Polonicx libri XII [...], ed. G. Groddeck (Leipzig: Gleditsch et Weidmann, 1711/12), X, 113.

${ }^{23}$ [Augustyn Rotundus,] Rozmowa Polaka z Litwinem 1564, ed. J. Korzeniowski (Kraków: Wydawn. Akademii Umiejętności w Krakowie, 1890), 67; [Augustinus Rotundus,] “Epitome Principum Lituaniae a migratione Italorum P. Libone vel, ut Lituanica historia scribit,
} 
the name Publius Libo, the Roman genealogy was extended to include Livonia as well as Lithuania. The ancient Roman colonizers had, supposedly, not only founded Lithuania, but had subjugated the lands further to the North as well, which became known as Libonia or Livonia after the conqueror's eponymous leader. It is hardly a coincidence that this tale appeared at a time when Lithuania was heavily involved in the Livonian War: If Livonia had once been the patrimony of their Roman ancestors, the Grand Duchy of Lithuania could legitimately claim the land against the competing ambitions of Muscovy and Sweden. ${ }^{24}$

The one major criticism voiced against Palemon, Libo and the alleged Roman origin of Lithuanians and Livonians was both simple and convincing: A Roman colony in the Baltic was not mentioned by any ancient source, and the Romans had never been shy to record their conquests. Thomas Hiärn (ca. 1638-1678), an eminent 17th century Livonian historiographer, voiced the skepticism shared by many of his contemporaries: “The Romans, who never failed to document everything that furthered their glory, would have never remained silent if they had possessed these lands." 25 Other scholars like Friedrich Menius (ca. 15941659) and Olaus Hermelin (ca. 1658-1709), professors at the University of Dorpat (Tartu), meticulously searched the ancient records for all prominent persons named either Palemon or Libo - and it seemed quite unlikely that men like Quintus Remmius Palaemon, a freed slave who later became a famous grammarian, or Marcus Scribonius Libo Drusus, who had been accused of necromancy and driven to suicide during the reign of emperor Tiberius, would have colonized Lithuania or Livonia. ${ }^{26}$

Nevertheless, numerous place names seemed to indicate that there had been some Roman influence on the eastern Baltic region, after all: Lithuania was supposedly a corrupted form of l'Italia, Lettonia was similarly deduced from Latium, and the city of Libau (Liepāja) and the river of the same name retained the name of Publius Libo. Romova, the temple site of

\footnotetext{
Palemone Duce usque ad Jagellones," in Studya nad stosunkami narodowościowemi na Litwie przed Uniq Lubelska, ed. J. Jakubowski, (Warszawa: Tow. Nauk. Warszawskiego, 1912), 95. Cf. Alvydas Nikžentaitis, "Historische Tradition und Politik. Litauen und der Ostseeraum vom 13. bis zum 20. Jahrhundert," in Beiträge zur Geschichte des Ostseeraumes. Vorträge der ersten und zweiten Konferenz der Ständigen Konferenz der Historiker des Ostseeraumes (SKHO). Katzow 1996 / Greifswald 1998, ed. H. Wernicke (Hamburg: Kovač, 2002), 229-231.

24 Niendorf, 60.

25 Thomas Hiärn, Ehst-, Lyf- und Lettländische Geschichte, ed. C. E. Napiersky (Riga: Frantzen, 1835), 21.

26 Fridericus Menius, "Syntagma de origine Livonorum," Scriptores rerum Livonicarum 2 (1848), 530; Olavus Hermelin, "De origine Livonorum disqvisitio," Scriptores rerum Livonicarum 2 (1848), 564.
} 
the pagan Prussians mentioned in the medieval chronicle of Peter of Dusburg, allegedly alluded to ancient Rome. ${ }^{27}$ For $16^{\text {th }}$ and $17^{\text {th }}$ century historians and ethnographers, who, like Caspar Peucer, relied heavily on the comparison of ethnonyms and toponyms, these were grave arguments indeed. Even more importantly, the linguistic similarities between classical Latin and the local idioms in Latvia and Lithuania seemed beyond doubt.

Summarily, the ancestors of Latvians and Lithuanians could not have been the Romans themselves - or else their exploits would have been recorded in ancient sources - but they spoke Latin, or a language similar to Latin, and retained a faint memory of Italy, its cities and provinces. These criteria soon led early modern commentators to turn towards present-day Romania: The Wallachians spoke a language that was acceptably close to Latin, and they lived much closer to Lithuania and Livonia, which made it seem far more likely that they had colonized the Baltic lands, rather than the Romans themselves. As scholars increasingly questioned the Lithuanian tradition, the Wallachians consequently began to replace the Romans as the ancestors of the Baltic nations.

\section{Wallachians and Heruls in the $17^{\text {th }}$ Century}

After Caspar Peucer, in the 1565 edition of the Chronicon Carionis, had introduced the Wallachian hypothesis to the academic elites of protestant Europe, it became a well-established feature in the historical accounts on Livonia. Matthias Strubycz, secretary of the Duke of Courland and author of the "Short and Accurate Historical-Geographical Description of the Duchy of Livonia" (Brevis atque Accurata Livoniz Ducatus Descriptio Historico-Geographica, 1577), was the first domestic historiographer who referenced Peucer's Wallachians in his writings. ${ }^{28}$ Among 17th century historiographers, the most notable proponent of the Wallachian genealogy was the infamous academic adventurer, bigamist and heretic Friedrich Menius, the first professor of history at the Academia Gustaviana at Dorpat (Tartu). ${ }^{29}$

In 1635, Menius published the first systematic inquiry into the origins of the Estonians and Latvians, entitled Syntagma de origine

\footnotetext{
27 Donecker 2010, 229.

${ }^{28}$ Matthias Strubyczius, Brevis atque Accurata Livoniæ Ducatus Descriptio Historico-Geographica [...], ed. J. L. Diezius (Amsterdam: Strander, 1727), 36. On Strubycz, cf. Katri Raik, Eesti-ja liivimaa kroonikakirjutuse kõrgaeg 16. sajandi teisel poolel ja 17. sajandi alul (Tartu: Tartu Ülikooli Kirjastus, 2004), 205-217.

${ }^{29}$ Cf. Stefan Donecker, "Arbeiten und Projekte des Dorpater Professors Friedrich Menius in den 1630er Jahren," Forschungen zur baltischen Geschichte 6 (2011): 31-60.
} 
Livonorum. ${ }^{30}$ Previous scholars like Peucer, Strubycz or Moritz Brandis, who compiled a history of Livonia on behalf of the Estonian nobility around 1600, had only touched the topic en passant in their writings. According to Menius, the Wallachians arrived in Livonia in the late $6^{\text {th }}$ century AD, the last major group of settlers before the arrival of the first German merchants in the $12^{\text {th }}$ century. In the preceding centuries, as Menius painstakingly explains, Livonia had been repeatedly invaded, conquered and colonized by a bewildering variety of Suebic and Gothic tribes and all kind of Scythian and Slavonic barbarians. The Wallachians intermingled with the local population and became the ancestors of both Latvians and Estonians. Their Latin heritage was the reason for the erroneous assumption of certain historiographers - Menius does not mention the Lithuanian humanists by name, but it is quite obvious to whom he is referring - who believed that Livonia had been colonized by Roman refugees. ${ }^{31}$

When scholars like Caspar Peucer or Friedrich Menius wrote about the Wallachi, they referred to the Romanian-speaking population of the lower Danube region, in its entirety - not only to the Principality of Wallachia, in the strict sense, but also to the inhabitants of Moldavia and Transylvania. According to Peucer, the Wallachians were the descendants of Roman and Byzantine soldiers who had been settled in the province of Dacia by the emperors.32 They later rebelled against their masters, instigated by the Sarmatians, who encouraged them to found colonies of their own and settle in Livonia and Lithuania. Friedrich Menius believed that the Wallachians were the offspring of intermarriages between Romans and Goths - a genealogy with far-reaching implications, to which I will return in the conclusion of the paper.

By the mid $17^{\text {th }}$ century, a new variation of the Wallachian hypothesis appeared. The somewhat generic term Wallachi for the inhabitants of the former Roman province of Dacia was replaced by a reference to the Heruls as the alleged ancestors of the Livonians. The Heruls, a somewhat elusive barbarian gens of the migration period documented in Greek and Roman sources between the $3^{\text {rd }}$ and the $6^{\text {th }}$ centuries ${ }^{33}$, had been supposedly rediscovered in northern Germany in the early $16^{\text {th }}$ century. Nicolaus Marschalk ( $\dagger$ 1525), a humanist at the

\footnotetext{
30 Stefan Donecker, "An Itinerant Sheep, and the Origins of the Livonians. Friedrich Menius' Syntagma de origine Livonorum (1635)," Journal of Baltic Studies 42 (2011) [forthcoming].

31 Menius, 532.

32 Melanthon and Peucerus, 457-458.

33 For a detailed, up-to-date discussion of the Heruls and the complex and shifting ethnic identities associated with the ethnonym, see Roland Steinacher, "The Herules: Fragments of a History," in Neglected Barbarians, ed. F. Curta (Turnhout: Brepols, 2011) [forthcoming].
} 
University of Rostock, reported that their descendants, the Weruli, lived in Mecklenburg, in his immediate vicinity. ${ }^{34}$ It seems that Marschalk's conjecture was inspired by the name of the local castle at Werle, in the vicinity of Güstrow - yet another of the onomastic speculations that were so typical for $16^{\text {th }}$ century historiography.

Wolfgang Lazius (1514-1565), rector of the University of Vienna, Habsburg court historiographer and one of the great men of letters of the mid $16^{\text {th }}$ century, referred to Marschalk's suggestion in his monumental volume on "The migrations of certain tribes" (De aliquot gentium migrationibus, 1557). He approved of the existence of Herulian remnants in Mecklenburg and added a peculiar detail: the text of the Lord's Prayer in the language of these "Weruli". ${ }^{35}$ Any reader familiar with the inhabitants of Livonia could not fail to notice that the text recorded by Lazius was identical with the Lord's Prayer in Latvian. From the perspective of early modern scholars, this conformity proved that the Latvians were descendants of the ancient Heruls.

Lazius had remarked that the "Werulian" prayer resembled corrupted Latin - a hint eagerly seized by Livonian historiographers looking for the origin of the local population: The Heruls were the perfect candidates to replace the Roman colonists of the Lithuanian chronicles and the Wallachians of Peucer and Menius as the ancestors of the indigenous Livonian peasantry: a famous tribe of the migration era, well documented in ancient sources and vaguely associated with eastern Europe, which spoke a kind of garbled Latin (which could explain the allegedly Latin toponyms in Livonia) and was, as Lazius had shown, closely related to the Latvians.

Only in 1858, the famous Baltic German historian Carl Schirren ${ }^{36}$ was able to show that generations of Livonian scholars had based their theory either on a major misunderstanding or even on a forgery: Lazius had copied the prayer text which he attributed to the "Weuli" of Mecklenburg from Sebastian Münster's "Cosmographia" (1550). There, it is correctly identified as the Lord's Prayer in the language of the peasants in the vicinity of Riga. ${ }^{37}$ It remains uncertain why Lazius decided to borrow

\footnotetext{
34 Nicolaus Mareschalcus, "Annalium Herulorum ac Vandalorum libri septem," in Monumenta inedita rerum Germanicarum pracipue Cimbricarum et Megapolensium [...], ed. E. J. de Westphalen (Leipzig: Martini, 1739-45), I, 332.

35 Wolfgang Lazius, De gentium aliquot migrationibus [...] (Basle: Oporinus, 1557), 787-788.

36 Carl Schirren, "Das Vaterunser der Heruler, als Plagiat erwiesen," Bulletin de la classe historico-philologique de l'Académie Impériale des Sciences de St.-Pétersbourg 16 (1859): 131-141.

37 Sebastian Munster, Cosmographey. Oder beschreibung Aller Länder herrschafftenn, ond fürnemesten Stetten des gantzen Erdbodens [...] (Basel: Henricpetri, 1588), 1119.
} 
the text, transfer it from Livonia to Mecklenburg and attribute it falsely to the descendants of the Heruls who supposedly lived there. Lazius was known to forge sources if that helped him to underpin his theories, but in this case he had no reason to do so - the genealogy of Heruls and Latvians was, to him, an issue of peripheral importance. It is equally possible that Lazius had no ulterior motives and simply confused his references. But regardless of his intentions, the one and only reason to include the Heruls in the genealogy of the Livonians was utterly invalid.

The dubious foundation of the Herulian hypothesis did not bother 17th century scholars: The Heruls started to replace the Wallachians as the ancestors of the Livonians, in particular the Latvians. As such, they were favoured by some of the most prominent local historiographers like Thomas Hiärn and Olaus Hermelin in Livonia, Albert Koiałowicz in Lithuania or Christophorus Hartknoch in Prussia. ${ }^{38}$ The connection to the lower Danube area and present-day Romania was, however, retained. According to the prevalent opinion, the Heruls had originated from the Roman province of Dacia and later colonized Livonia. Alternatively, it was suggested that they originally came from the Baltic, migrated to Dacia, adopted the Latin language there and subsequently brought it back to Livonia, their homeland, when they returned. This opinion was endorsed by Olaus Hermelin, an influential Swedish professor at the University of Tartu during the 1690s: "It seems very likely," Hermelin wrote, "that the Latvian language and the Latvian nation originate from a tribe that migrated from Dacia in the years after Emperor Aurelianus. [...] The Heruls had received Dacia in the $6^{\text {th }}$ century from Justinian. Based on the similarity in language and manners, it is probable that the Latvians and Lithuanians originate from them. This means that the Latin language was not brought to Livonia by the Romans, but rather by autochthonous inhabitants who had once left this land and were now returning." 39

\section{Conclusions: Livonia and Wallachia, Migrations and the Politics of Antiquity}

Long-distance migrations of valiant conquering tribes, distant settlements and remote colonies were one of the favorite topics among early modern historiographers. The English clergyman William Nicholls

\footnotetext{
38 Hiärn, 22-25, 57; Hermelin 586; Albertus Wiivk Koialowicz, Historia Litvanæ Pars prior; de rebus Litvanorom Ante susceptam Christianam Religionem, conjunctionemque Magni Litvanix Ducatus cum Regno Poloniæ libri novem (Danzig: Förster, 1650), 6; Christophorus Hartknoch, Alt- und Neues Preussen Oder Preussischer Historien Zwey Theile [...] (Frankfurt and Leipzig: Hallervorden, 1684), 94-96, 222.

${ }^{39}$ Hermelin, 586.
} 
(1664-1712), to quote but one example, verbalized his contemporaries' fascination with migration in 1696: "[T] here is nothing more famous in Ancient History, than these transmigrations of Inhabitants from one Country to another. Every one knows of Cadmus's Plantation in Bœotia, of his brother Cilix in Cilicia, of Dido's in Africa; of the Colonies settled by Evander, Æneas, and Diomedes in Italy; to say nothing of our English Brute and the swarming Invasions of the Saxons and Danes, and a hundred other Instances. For there is hardly any Nation almost, but owes their Original to some Colony planted there, within the reach of History." 40 In 1750, the historiographers' preoccupation with large-scale migration received a lapidary comment in the authoritative "Universal-Lexicon" of Johann Heinrich Zedler: "There is hardly anything more common in history than the constant talk about the so-called migrations of various peoples." 41

To early modern men of letters, migration was not only an important feature of the human condition, but literally the driving force behind all human history. The unquestionable belief in the literal truth of the Old Testament meant that all humans were descendants from Noah's family, implying that everybody had, at one time or the other, migrated from the stranded Ark at Mount Ararat or the Tower of Babel on the Plains of Shinar. Among the previously mentioned Livonian historiographers, Friedrich Menius was particularly outspoken in his emphasis on the universality of migration: Christian scholars could never possibly agree to the tales of autochthony found in Tacitus and other ancient sources, since the Holy Scriptures unequivocally testify that all mankind originated from Noah. No nation can therefore claim to be indigenous in the land it currently inhabits. ${ }^{42}$

\footnotetext{
40 William Nicholls, A Conference with a Theist (London: T. W., 1696), 67.

41 Johann Heinrich Zedler, Grosses vollständiges Universal-Lexicon Aller Wissenschaften und Künste [...]. Vol. 63 (Leipzig and Halle: Zedler, 1750), 1269-1272. The article continues with a scathing criticism of the exaggerated enthusiasm for conquering, migrating tribes and their importance in history.

42 Menius, 517. Menius' statement mirrors the opinion of French scholar Jean Bodin, who belonged to the most authoritative theorists of historiography in the early modern period. Bodin had vehemently criticized the German humanists who prided themselves on the autochthony of the old Germans that Tacitus had described: "Althamer, imitating Tacitus, [...] wrote that the Germans were born in Germany itself and were not descended from any other race. [...] What more stupid, shall I say, or more impious can be imagined than this? The ancients, of course, in a certain sense deserve indulgence; but modern people are either guilty of great error or of sin, both because they contradict the statements made by Moses about primitive times in the Holy Scriptures [...] and because they separate these races altogether from association and friendship by assuming for them no source other than the ancestral soil." Jean Bodin, Method for the Easy Comprehension of History, ed. B. Reynolds (New York: Norton, 1969), 334-335.
} 
When confronted with surprising cultural similarities - linguistic resemblances, religious practices, traditions and customs etc. - between distant populations, early modern scholars tended to rely on complex narratives of long-distant migration as an explanation: Cultural carriers allegedly broke away from their original settlements and moved to other parts of the world. Alternative modes of explanation - such as the transfer of cultural traits between stationary ethic groups through imitation, i.e. "diffusion" in the terms of modern cultural anthropology 43 - were hardly considered during the $16^{\text {th }}$ and $17^{\text {th }}$ centuries. According to this prevalent migration paradigm, the alleged similarities between Latvian, Lithuanian and Latin and the ominous toponyms in Livonia which seemed somewhat Roman-inspired had to be explained as the result of Roman colonisation in the Baltic area, later rationalized as an indirect Romanesque influence with Wallachian or Herulian settlers as the intermediaries.

In his famous 1994 monograph "Inventing Eastern Europe. The Map of Civilization on the Mind of the Enlightenment", Larry Wolff emphasized the role of scholarly antiquarianism in the "philosophical geography" of the $18^{\text {th }}$ century. In their perception of the lands that became categorized as "Eastern Europe", enlightenment authors repeatedly referred to the various tribes that had inhabited the area in antiquity. Contemporary observations and recent travelers' reports were combined with scholarly knowledge drawn from classical Greek and Roman literature to conceptualize Eastern Europe as the barbarian antithesis to the civilized West - a process aptly characterized by Wolff as a "collapsing of chronology". 44

A similar argumentative technique was employed by previously mentioned scholars like Friedrich Menius and Olaus Hermelin, roughly a century before the enlightenment "invention" of Eastern Europe. References to the ancient inhabitants of Livonia and the putative ancestors of the Estonians and Latvians enabled 17th century scholars to express their opinions on contemporary matters, and sometimes contained thinly veiled allusions to controversial political issues. The various theories on Wallachian and Herulian settlements in the Baltic might seem, at first glance, to be little more than eccentric creativity of armchair intellectuals, but they provide modern researchers with interesting perspectives on the world-view of the respective scholars. It was, I believe, no coincidence that

43 Cf. Annemarie de Waal Malefijt, Images of Man. A History of Anthropological Thought (New York: Knopf, 1974), 160-161.

${ }^{44}$ Larry Wolff, Inventing Eastern Europe. The Map of Civilization on the Mind of the

Enlightenment (Stanford: Stanford University Press, 1994), 285. 
humanist men of letters constructed a link between the Baltic and the Black Sea area, fictitious to us but quite factual to them.

What conclusions can thus be drawn from the idea that Livonia had been colonized by settlers from present-day Romania? How did $16^{\text {th }}$ and 17th century men of letters perceive the Baltic and the Black Sea littoral, and the connection between these two regions established by the putative migration of Wallachians and Heruls?

In the first place, the Livonian-Wallachian migration theory indicates that both lands, Livonia as well as Wallachia, were seen as fringes of European civilization, where major migrations and colonizations could occur without being noticed. This was, after all, the main reason why the Wallachians were preferred to the Romans in these tales of descent. If the Romans had colonized Livonia, it would have been mentioned in ancient sources. If the settlers had been Wallachians, from the frontier of the Roman-Mediterranean world, close to barbarian Scythia, such a migration could have easily remained unnoticed.

Secondly, and possibly more importantly: The Wallachian respectively Herulian theory bestows a rather prestigious genealogy on the Livonian peasants. Wallachians were indeed ancestors to be proud of: For Friedrich Menius, the Wallachians were ex Italis et Gothis mixti ${ }^{45}$ - the offspring of the union between the noble Romans and the warlike Goths, both of whom were extremely popular during the $17^{\text {th }}$ century. The prestige which the ancient Romans, as the founders of European civilization, had acquired in the wake of the humanist rediscovery of classic antiquity is beyond dispute. The Goths, however, were almost equally renowned among the scholars of $17^{\text {th }}$ century north-eastern Europe. Swedish chroniclers had developed an extremely elaborate historical narrative which extolled the deeds of the Goths, the alleged ancestors of the Swedes. The bravery of the Goths, they claimed, was unmatched, and it was complimented by their unswerving loyalty, an exemplary godliness and all kinds of innate virtues. So-called "Gothicism" provided the ideological foundation of the expansionist policies of the Swedish kingdom during the 17th century, and exerted a considerable influence on historiography and learned antiquarianism all over north-eastern Europe.46 When Menius credited the Livonians with a Roman-Gothic heritage, he implied that they

\footnotetext{
45 This explanation is omitted in the 1848 reprint. It can be found in the original edition: Friedericus Menius, Syntagma De Origine Livonorum (Dorpat: 1635), 74.

${ }^{46}$ Cf. Kristoffer Neville, "Gothicism and Early Modern Historical Ethnography," Journal of the History of Ideas 70 (2009): 213-234; Inken Schmidt-Voges, De antiqua claritate et clara antiquitate Gothorum. Gotizismus als Identitätsmodell im frühneuzeitlichen Schweden (Frankfurt: Lang, 2004).
} 
were, in a way, the "best of both worlds", combining Roman civilization and Gothic valor.

Olaus Hermelin's version of the tale is equally appreciatory: According to his treatise, the Herulian ancestors of the Latvians managed to acquire Latin culture and Latin civilization all by themselves. They did not depend on anybody else to civilize and enlighten them, but accomplished this feat independently from any foreign influence - in the course of their migration to Romania and back. Hermelin's academic readers would not have failed to recognize and appreciate this remarkable achievement.

It was no mere coincidence that scholars like Menius or Hermelin constructed such a prestigious origin for the peasants of Livonia. The socalled "peasant question" was an issue of considerable importance in the struggle between the local Baltic German nobility, determined to preserve their traditional liberties and privileges, and the centralization efforts of Swedish absolutism. Swedish demands for a better treatment of the Estonian and Latvian peasantry were an apt measure to exert pressure on the nobility, whose prosperity depended on the strict system of serfdom. ${ }^{47}$ A prestigious Wallachian-Herulian genealogy was a powerful argument: If the Latvian or Estonian peasants were the descendants of such noble ancestors, it would be most inappropriate to maintain the status quo and force them to endure humiliating serfdom. It is hardly surprising that both Menius and Hermelin, as professors at the University of Dorpat with close ties to Swedish centralism, advocated such a benevolent interpretation of ancient Livonian history.

In the historical imagination of early modern scholars, the past of different European regions was linked by a web of far-reaching migrations. The alleged connection between the Baltic Sea and the Black Sea area allowed $17^{\text {th }}$ century scholars to express a positive attitude towards the indigenous peasants of Livonia. On their mental maps, Dacia respectively Wallachia were not too civilized - which would have been incompatible with a credible migration theory, as the Romanian-Lithuanian example had shown -, but still civilized enough to provide a reputable and very prestigious ancestry. A Wallachian origin was, indeed, an honorable genealogy.

${ }^{47}$ Cf. Marten Seppel, “ Die Entwicklung der 'livländischen Leibeigenschaft' im 16. und 17. Jahrhundert,“ Zeitschrift für Ostmitteleuropa-Forschung 54 (2005): 174-193. 


\section{References:}

\section{A. Early Modern Sources}

Bodin, Jean. Method for the Easy Comprehension of History. Ed. Beatrice Reynolds. New York: Norton, 1969.

Długossus, Ioannes. Historiæ Polonicæ libri XII [...]. Ed. Gabriel Groddeck. Leipzig: Gleditsch et Weidmann, 1711/12.

Hartknoch, Christophorus. Alt- und Neues Preussen Oder Preussischer Historien Zwey Theile [...]. Frankfurt and Leipzig: Hallervorden, 1684.

Hermelin, Olavus. "De origine Livonorum disqvisitio." Scriptores rerum Livonicarum 2 (1848) : 543-566.

Hiärn, Thomas. Ehst-, Lyf- und Lettländische Geschichte. Ed. Carl Eduard Napiersky. Riga: Frantzen, 1835.

Koialowicz, Albertus Wiivk. Historia Litvanæ Pars prior; de rebus Litvanorvm Ante susceptam Christianam Religionem, conjunctionemque Magni Litvanix Ducatus cum Regno Poloniæ libri novem. Danzig: Förster, 1650.

Lazius, Wolfgang. De gentium aliquot migrationibus [...]. Basel: Oporinus, 1557.

Melanthon, Philippus and Casparus Peucerus. Chronicon Carionis expositum et auctum [...] ab exordio mundi usque ad Carolum V. Imperatorem. Wittenberg: Krafft, 1580.

Mareschalcus, Nicolaus. "Annalium Herulorum ac Vandalorum libri septem." In Monumenta inedita rerum Germanicarum pracipue Cimbricarum et Megapolensium [...]. Ed. Ernestus Joachimus de Westphalen. Leipzig: Martini, 1739-45, I, 165-340.

Menius, Fridericus. "Syntagma de origine Livonorum." Scriptores rerum Livonicarum 2 (1848) : 511-542.

Munster, Sebastian. Cosmographey. Oder beschreibung Aller Länder herrschafftenn, ond fürnemesten Stetten des gantzen Erdbodens [...]. Basel: Henricpetri, 1588.

Nicholls, William. A Conference with a Theist. London: T. W., 1696.

Rotundus, Augustyn. Rozmowa Polaka z Litwinem 1564. Ed. Józef Korzeniowski. Kraków: Wydawn. Akademii Umiejętności w Krakowie, 1890.

Rotundus, Augustinus. "Epitome Principum Lituaniae a migratione Italorum P. Libone vel, ut Lituanica historia scribit, Palemone Duce usque ad Jagellones." in Studya nad stosunkami narodowościowemi na Litwie przed Unia Lubelską. Ed. Jan Jakubowski. Warszawa: Tow. Nauk. Warszawskiego, 1912, 94-104. 
Strubyczius, Matthias. Brevis atque Accurata Livoniæ Ducatus Descriptio Historico-Geographica [...]. Ed. Justus Laurentius Diezius. Amsterdam: Strander, 1727.

Zedler, Johann Heinrich. Grosses vollständiges Universal-Lexicon Aller Wissenschaften und Künste [...]. Leipzig and Halle: Zedler, 1732-54.

\section{B. Modern Literature}

Donecker, Stefan. Origines Livonorum. Frühneuzeitliche Hypothesen zu Herkunft und Ursprung der 'undeutschen' Livländer. PhD thesis, Florence: EUI, 2010.

Donecker, Stefan. "Arbeiten und Projekte des Dorpater Professors Friedrich Menius in den 1630er Jahren." Forschungen zur baltischen Geschichte 6 (2011): 31-60.

Donecker, Stefan. "An Itinerant Sheep, and the Origins of the Livonians. Friedrich Menius' Syntagma de origine Livonorum (1635)." Journal of Baltic Studies 42 (2011) [forthcoming].

Goetz, Hans-Werner. "'Konstruktion der Vergangenheit'. Geschichtsbewusstsein und 'Fiktionalität' in der hochmittelalterlichen Chronistik, dargestellt am Beispiel der Annales Palidenses." In Von Fakten und Fiktionen. Mittelalterliche Geschichtsdarstellungen und ihre kritische Aufarbeitung. Ed. Johannes Laudage. Köln: Böhlau, 2003, 225-257.

Johansen, Paul. “Die Legende von der Aufsegelung Livlands durch Bremer Kaufleute." In Europa und Übersee. Festschrift fur Egmont Zechlin. Ed. Otto Brunner and Dietrich Gerhard. Hamburg: Hans Bredow-Institut, 1961, 4268.

Kulicka, Elżbieta. "Legenda o rzymskim pochodzeniu Litwinów i jej stosunek do mitu sarmackiego." Przeglad Historyczny 71 (1980): 1-21.

Malefijt, Annemarie de Waal. Images of Man. A History of Anthropological Thought. New York: Knopf, 1974.

Neville, Kristoffer. "Gothicism and Early Modern Historical Ethnography." Journal of the History of Ideas 70 (2009): 213-234.

Niendorf, Mathias. Das Großfürstentum Litauen. Studien zur Nationsbildung in der Frühen Neuzeit (1569-1795). Wiesbaden: Harrassowitz, 2006.

Nikžentaitis, Alvydas. "Historische Tradition und Politik. Litauen und der Ostseeraum vom 13. bis zum 20. Jahrhundert." In Beiträge zur Geschichte des Ostseeraumes. Vorträge der ersten und zweiten Konferenz der Ständigen Konferenz der Historiker des Ostseeraumes (SKHO). Katzow 1996 / Greifswald 1998. Ed. Horst Wernicke. Hamburg: Kovač, 2002, 225-235.

Pohlig, Matthias. Zwischen Gelehrsamkeit und konfessioneller Identitätsstiftung. Lutherische Kirchen- und Universalgeschichtsschreibung 1546 - 1617. Tübingen: Mohr Siebeck, 2007. 
Prietz, Frank. "Geschichte und Reformation. Die deutsche Chronica des Johannes Carion als Erziehungsbuch und Fürstenspiegel." In Universitas. Die mittelalterliche und frühneuzeitliche Universität im Schnittpunkt wissenschaftlicher Disziplinen. Georg Wieland zum 70. Geburtstag. Ed. Oliver Auge and Cora Dietl. Tübingen and Basel: Francke, 2007, 153-165..

Raik, Katri. Eesti-ja liivimaa kroonikakirjutuse kõrgaeg 16. sajandi teisel poolel ja 17. sajandi alul. Tartu: Tartu Ülikooli Kirjastus, 2004.

Schirren, Carl. "Das Vaterunser der Heruler, als Plagiat erwiesen." Bulletin de la classe historico-philologique de l'Académie Impériale des Sciences de St.Pétersbourg 16 (1859): 131-141.

Schmidt-Voges, Inken. De antiqua claritate et clara antiquitate Gothorum. Gotizismus als Identitätsmodell im frühneuzeitlichen Schweden. Frankfurt: Lang, 2004.

Seppel, Marten. “Die Entwicklung der 'livländischen Leibeigenschaft' im 16. und 17. Jahrhundert." Zeitschrift für Ostmitteleuropa-Forschung 54 (2005): 174-193.

Steinacher Roland. "The Herules: Fragments of a History." In Neglected Barbarians. Ed. Florian Curta. Turnhout: Brepols, 2011 [forthcoming].

Stupperich, Robert. "Melanchthon und Hermann Wittekind über den livländischen Krieg." Zeitschrift für die Geschichte des Oberrheins 103 (1955): 275-281.

Tereškinas, Artūras. Imperfect Communities. Identity, Discourse and Nation in the Seventeenth-Century Grand Duchy of Lithuania. Vilnius: Lietuviu literatūros ir tautosakos institutas, 2005.

Wolff, Larry. Inventing Eastern Europe. The Map of Civilization on the Mind of the Enlightenment. Stanford: Stanford University Press, 1994.

Ziegler, Hildegard. Chronicon Carionis. Ein Beitrag zur Geschichtschreibung des 16. Jahrhunderts. Halle: Niemeyer, 1898. 